\title{
Az Gelişmiş Bir Destinasyonda Yerel Halkın Turizme Yönelik Desteği: Yozgat Örneği
}

\author{
Residents' Support for Tourism Development in an Underdeveloped Destination: The Case of Yozgat
}

\section{Ozan ATSIZ*}

* Arş. Gör. Dr., Turizm Fakültesi, Gastronomi ve Mutfak Sanatları, Yozgat Bozok Üniversite-si, Azizli, Yozgat, 66200, Türkiye.

E-posta: ozan.atsiz@bozok.edu.tr

ORCID: 0000-0003-2962-1903

\section{MAKALE BILGILERI \\ Makale işlem bilgileri: \\ Gönderilme tarihi:16 Mart 2021 \\ Düzeltme: 15 Temmuz 2021 \\ Düzeltme: 16 A ğustos 2021 \\ Kabul: 8 Eylül 2021}

Anahtar sözcükler: Turizme destek, Turizm algısı, Yerel halk, Topluluğa bağhllı, Genel yaşam kalitesi, Yozgat.

\section{ARTICLE INFO}

Article history:

Submitted: 16 March 2021

Resubmitted: 15 July 2021

Resubmitted: 16 August 2021

Accepted: 8 September 2021

Key words: Support for tourism, Tourism perception, Local people, Community attachment, Overall quality of life, Yozgat (Turkey).

\section{ÖZ}

Bu çalışmanın amacı, turizm açısından az gelişmiş bir destinasyonda yerel halkın turizme yönelik desteğini incelemektir. Bu kapsamda, yerel halkın turizmle ilgili algıladığı olumlu ve olumsuz etkiler, genel yaşam kalitesi, topluluğa bağlılık ve turizme destek değișkenleri arasındaki ilișkiyi ölçebilmek için yapısal bir model ortaya koyulmuștur. Bu doğrultuda, Yozgat ilinde ikamet eden 457 kișiden anket tekniği ile veri toplanmıștır. Kısmi en küçük kareler tabanlı yapısal eşitlik modellemesi sonucu ortaya çıkan araştırma bulgularına göre, turizmin algılanan olumlu etkilerinin turizme desteği olumlu yönde etkilediği; algılanan olumsuz etkilerin ise turizme desteği olumsuz yönde etkilediği görülmüștür. Bununla beraber, turizm geliștiğinde algılanan olumlu etkilerin yerel halkın yaşam kalitesini etkileyeceği ortaya koyulmuştur. Ayrıca, yerel halkın yaşam kalitesinin etkileneceği algısı da turizme desteği etkilemektedir. Son olarak, yerel halkın topluluğa bağı olma düzeyi, turizmin algılanan olumlu etkilerini ve yerel halkın turizme desteğini etkilemektedir.

\begin{abstract}
This study aims to explore residents' support for tourism in an underdeveloped tourism destination. In this regard, a structural model to test the relationships among variables such as residents' perceived effects toward tourism, overall quality of life, community attachment and support for tourism has been put forward. The research data were collected from 457 residents in Yozgat (Turkey) through a questionnaire. According to research findings from partial least squares structural equation modelling, positive perceptions of tourism effects positively influence support for tourism while negative ones negatively influence this support. The study also reveals that positive perceptions of tourism effects influence residents' overall quality of life. Moreover, residents' perceived expectations of overall quality of life have effects on the support for tourism. Finally, community attachment affects positive perceptions of tourism effects and support for tourism.
\end{abstract}

\section{Giriş}

Turizm gelişimi, kırsal ya da kentsel destinasyonlarda bölgenin kalkınması ve ekonominin canlandırılması açısından önemlidir (Chen ve Chen 2010). Fakat bu gelişimin başarılı bir şekilde gerçekleşebilmesi genellikle yerel halkın turizme yönelik olumlu düşünceleri ve katılımı ile mümkündür (Ap ve Crompton 1998). Yerel halkın turizmin gelişmesine yönelik algılarının ortaya koyulması, yerel halkın turizmin gelişimine ilişkin desteğini anlamak açısından gereklidir (Perdue vd. 1990). Ayrica, yerel halkın turizme destek vererek katılımda bulunması, sürdürülebilir turizm gelişiminin ayrılmaz bir parçasıdır (Obradović ve Stojanović 2021). Çünkü yerel halkın turizme katılım göstermesi, turizm ile ilgili stratejilerin oluşturulması, destinasyonda sunulan ürün ve hizmetlerin geliştirilmesi açısından önemli bir role sahiptir (Çiçek ve Sarı 2018). Gelişmiş, gelişmekte olan ya da az gelişmiş destinasyonlar yerel halkın desteğini alabilmek ve bu desteği güçlendirebilmek için yerel halkın algılarını ve desteğini anlamaya çalışmaktadır (Liang vd. 2021). Bu 
durum, turizmin az geliştiği destinasyonlarda daha önemlidir (Rasoolimanesh ve Jaafar 2016).

Turizmin geliştiği bölgelerde, yerel halkın turizmin gelişmesine yönelik algıları turizm alanyazınında kapsamlı bir şekilde incelenmiş (Liang vd. 2021) ve ekonomik, sosyal ve çevresel etkiler olmak üzere üç başlık altında ele alınmıştır (Rasoolimanesh ve Jaafar 2016). Yerel halkın desteğinin belirtilen bu algılara bağlı olduğu kabul edilse de, bu ilişkinin yapısal etkilerinin yeterin-

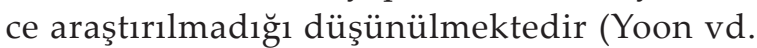
2001). Yapılan çalışmalara göre, turizme destek yerel halkın yaşam kalitesinden duyduğu memnuniyet düzeyi ve topluluğa bağlılığ1 yanında destinasyonun kimlik algısı ile de ilişkili olabilmektedir (Mccool ve Martin 1994; Moscardo 2009; Eslami vd. 2019). Turizm gelişiminin farklı aşamalarında olan bölgelerde yapılan araştırmalar, yerel halkın turizm etkileri odaklı algısı ve turizm gelişimine olan desteğini anlamak açısından ilgili alana ve yöneticilere katkı sağlamaktadir (Chen ve Chen 2010).

Önceki çalışmalar genellikle turizm açısından gelişmiş veya gelişmekte olan destinasyonlar üzerinde uygulanmıştır. Bununla birlikte, az gelişmiş destinasyonlar üzerine yapılan çalışmaların az sayıda olduğu görülmektedir (Çelik ve Rasoolimanesh 2021). Bu çalışmalarda, yerel halkın turizme yönelik olumlu ve olumsuz alg1 düzeylerinin, turizme destek düşüncesi ile sinırlı kaldığ görülmektedir (Rasoolimanesh ve Jaafar 2016; Çelik ve Rasoolimanesh 2021). Yerel halkın topluluğa bağlılığ ve yaşam kalitesine ilişkin memnuniyet düzeyi ile ilgili konuların araştırmacılar tarafından yeterince araştırılmadığı görülmüştür. Bu kapsamda, bu çalışmanın amacı turizm açısından gelişmemiş bölgelerden biri olan Yozgat'ta yerel halkın turizme yönelik desteğini ve bu desteğin yerel halkın toplumsal bağlilık düzeyi, turizme yönelik algılanan olumlu ve olumsuz etkileri, yaşam kalitesinden duyulan memnuniyet düzeyi ile ilişkilerini incelemektir.

Bu çalışma, az gelişmiş destinasyonlarda yerel halkın turizme desteğinin düzeyi ve etkilerinin anlaşılabilmesine katkıda bulunmaktadır. Araştırmada test edilen modelde, turizme destekte rol alan etkenler belirlendiğinden, turizm gelişi- miyle ilgili yerel halka ait sorumluluklar ortaya koyulabilecektir. Bu doğrultuda çalışma, yerel halkın turizme yönelik desteğini saptayarak gelecekte yapılacak araştırmalara yol göstermektedir. Aynı zamanda elde edilen araştırma bulguları 1şığında, destinasyon yöneticilerinin ve yerel halkın yönlendirilmesi ile, bölgedeki turizm faaliyetlerinin gelişimine katkı sunulması hedeflenmektedir.

\section{KURAMSAL ÇERÇEVE}

Turizme destek kavramı, yerel halk tarafından turizmin algilanan olumlu ve olumsuz etkileri sonucunda geliştirdikleri tepki olarak belirtilmektedir (Perdue vd. 1990). Geliştirilen bu tepki zihinsel ve duygusal olabileceği gibi fiziksel de olabilmektedir (Tosun 2006). Yerel halkın turizme desteğini etkileyen birçok faktör bulunmaktadır. Bunlardan ilki, yerel halkın turizm etkilerine yönelik algılarıdır. Yerel halkın turizmin etkilerine yönelik algılarını inceleyen birçok çalışma bulunmaktadır (Perdue vd. 1990; Gursoy vd. 2002; Nunkoo ve Ramkissoon 2011b; Nunkoo ve Gursoy 2012; Rasoolimanesh ve Jaafar 2016; Çelik ve Rasoolimanesh 2021; Liang vd. 2021). Bu çalışmalara göre, turizmin algılanan etkileri, ekonomik, sosyal ve çevresel etkiler olmak üzere üç farklı başlık altında ele alınmaktadır. Yerel halkın turizme yönelik algıladıkları olumlu ekonomik etkiler; gelir düzeyinin artması, istihdam olanaklarının yaratılması ve yaşam standardının geliştirilmesi olarak sıralanırken; olumsuz etkileri ise yaşam maliyetlerinin (ürünlerin ve hizmetlerin fiyatlarında genel artış) ve emlak vergilerinin artması olarak belirlenmektedir. Turizm gelişiminin olumlu sosyal etkileri kapsamında ise; rekreasyon faaliyetlerinin ve eğlence tesislerinin artırılması, bu tesis ve faaliyetlerin kalitelerinin iyileştirilmesi, bölgenin kültürel kimliğinin ortaya çıkarılması ve tanıtımı, bölgenin geleneğinin, sanatının, kültürünün ve zanaatlarının canlandırılması ve korunması yer almaktadır. Turizm gelişiminin olumsuz sosyal etkileri ise; aile yapısının bozulması, aşırı kalabalıklaşma, trafiğgin artması, suç oranlarının ve uyuşturucu kullanımının artması olarak belirtilmektedir. Öte yandan doğal çevrenin ve ekosistemin zarar görmesi, hava, su 
ve çevresel kirlenmede artışın gözlemlenmesi de algılanan olumsuz çevresel etkilerinden birkaçıdır.

Tüm bu etkilere ilişkin yerel halkın algıları, farklı teoriler ve modeller (Sosyal Değişim Teorisi, Turizm Yaşam Döngüsü Modeli, Tolerans Modeli, Kimlik Teorisi, Sosyal Temsil Teorisi, Büyüme Makinesi Kuramı ve Planlanmış Davranış Teorisi) kullanılarak incelenmiştir (Gursoy ve Nunkoo 2019). Bunlardan en fazla kullanılan ve kabul gören kuramlardan biri Sosyal Değişim Teorisi olmuştur (Nunkoo vd. 2013). Perdue ve diğerleri (1990) bu kuramin yerel halkın turizmin etkilerine ilişkin algılarını anlamak açısından uygun bir çerçeve sunduğunu belirtmişlerdir. Ap'a (1992) göre bu kuram, sosyolojik bir niteliğe sahip olmakla beraber etkileşime giren bireyler ve gruplar arasındaki kaynak değişimini anlamaya ve ortaya koymaya çalışır. Bu kurama göre, yerel halk turizmden fayda sağladıkça turizme destek verirken turizmin olumsuz yönlerini hissettikçe destek vermemektedir. Bu doğrultuda, yerel halkın turizme vermiş olduğu destek algıladığ fayda ile doğru orantılı iken, algılanan maliyet ile ters orantılıdır (Çiçek ve Sarı 2018). Yukarıda sözü edilen, yerel halkın turizme yönelik algıladığ 1 olumlu etkiler algılanan fayda olarak nitelendirilirken, olumsuz etkiler ise algilanan maliyet olarak nitelendirilmektedir (Nunkoo ve Ramkissoon 2011b).

Topluluğa bağl1lık kavramı, insanların güçlü olumlu duyguları, topluluğun köklü bir geçmişe sahip olması ve aidiyet duygusu çerçevesinde açılanan sosyolojik bir kavramdır (Brehm vd. 2004). Topluluğa bağlılık kavramını turizm gelişimi açısından ele alan ilk araştırmacılardan Mccool ve Martin (1994), bu kavramı sosyal bütünleşme ve sosyal katılım ile açıklamıştır. Ayrıca, topluluğa bağlılık insanların kendi toplumlarına karşı sahip oldukları hisler bütünü olarak değerlendirilmiştir (Mccool ve Martin 1994). Yerel halkın içinde bulunduğu topluluğa bağlıl1ğ1 ne kadar yüksekse turizm gelişimine desteği o düzeyde yüksek olmaktadır (Brehm vd. 2004; Eslami vd. 2019). Bu doğrultuda, turizm alanyazınında topluluğa bağlılık kavramı, turizmin gelişimiyle ilişkilendirilmeye çalışılmıştır. Ayrıca, topluluğa bağlılık genellikle ikamet edilen süre, doğum yeri ve bölgeye ilişkin ortak bir mirası- nın olup olmadığ ve Crompton 1987). Mccool ve Martin (1994), çalışmalarında topluluğa bağlılık ve ikamet edilen süre arasında zayıf bir ilişki olduğunu ve turizm gelişimini destekleyenlerin bölgede kısa süreliğine ikamet ettiğini ortaya koymuştur.

Genel olarak turizm gelişiminin temel amac1, turizmin ekonomik, sosyal, kültürel ve çevresel faydalarını göz önünde tutarak yerel halkın yaşam kalitesini artırmaktır (Mccool ve Martin 1994). Çünkü yerel halkın yaşam kalitesi arttığ1 ölçüde, turizme yönelik desteği sürmektedir (Woo vd. 2015). Yaşam kalitesi genel olarak, bireyin refahı, tatmini-tatminsizliği veya hayattan mutlu-mutsuz olması şeklinde değerlendirilmektedir (Eslami vd. 2019). Bu bağlamda, yaşam kalitesiyle ilgili beklentiler de turizm gelişimiyle ilgili dikkate alınması gereken bir durum olarak ortaya çıkmaktadır.

\section{Araştırma Modeli ve Hipotezler}

Turizm alanyazınında yerel halkın turizme yönelik algılanan olumlu ve olumsuz algılarının turizme desteğine olan etkisini ölçen birçok çalışma yer almaktadır (Perdue vd. 1990; Nunkoo ve Ramkissoon 2011b; Nunkoo ve Gursoy 2012). $\mathrm{Bu}$ çalışmalara göre, yerel halk turizmin ekonomik, sosyo-kültürel ve çevresel etkilerini olumlu olarak algiladığında turizme destek vermekte ve planlamalara katılmak suretiyle katkıda bulunmaktadır. Bu etkileri olumsuz olarak algıladığı zaman ise turizme desteği ve turizm planlamasina katkısı sinırlı kalmaktadır (Gursoy vd. 2002; Nunkoo ve Ramkissoon 2011a; Sharpley 2014). $\mathrm{Bu}$ durum turizm gelişiminin sürdürülebilirliğini etkilemektedir. Yukarıda bahsedildiği üzere, bu etkiler yoğun olarak Sosyal Değişim Teorisi kapsamında incelenmiştir (Nunkoo vd. 2013). Bu nedenle, bu çalışma da söz konusu teori bağlamında yapılandırılmıştır. Bu teoriye göre yerel halk, turizmin olumlu etkilerinin veya faydalar1nın olumsuz etkilerinden veya maliyetlerinden daha ağır bastığını algıladığında, turizme olumlu destek sunacaktır (Ap 1992). Algılanan bu etkilerin ve yerel halkın turizme desteği boyutu arasındaki ilişkiyi az gelişmiş destinasyonlarda inceleyen sınırlı sayıda çalışma yer almaktadır 
(Rasoolimanesh ve Jaafar 2016; Çelik ve Rasoolimanesh 2021). Bu çalışmalara göre, altyapı, kamu tesisleri, yatırımlar ve istihdam olanaklarının artacağ alg$_{1 S 1}$, turizmin gelişim öncesi aşamasında turizm gelişimine verilecek muhtemel desteğ $\mathrm{i}$ göstermektedir. Ayrıca bu çalışmalarda, algılanan olumsuz etkiler kapsamında trafiğin yoğunlaşması, gürültünün, hava kirliğinin, yaşama maliyetlerindeki ve olası suç oranlarının artacağı algısı ortaya konmaktadır. Tüm bu bulgulardan hareketle, $\mathrm{H} 1$ ve $\mathrm{H} 2$ hipotezleri aşağıdaki gibi belirlenmiştir:

$\mathrm{H}_{1_{\text {O/A }}}$ : Turizmin algilanan olumlu etkilerinin turizme destek üzerinde etkisi yoktur/vardır.

$\mathrm{H}_{2 / \mathrm{A}}$ : Turizmin algllanan olumsuz etkilerinin turizme destek üzerinde etkisi yoktur/vardır.

Yerel halkın algıladı $\breve{g}_{1}$ turizmin olumlu ve olumsuz etkileri yerel halkın yaşam kalitesini ya da yaşam memnuniyetini de etkileyebilmektedir (Su vd. 2018). Yerel halkın algıladığı turizmin olumlu etkilerinin yerel halkın yaşam kalitesini etkilediğine dair alanyazında birçok çalışma bulunmaktadır (Moscardo 2009; Guo vd. 2014; Woo vd. 2015). Buna göre, yerel halkın algılad1ğ1 olumlu turizm etkileri yaşam kalitesi üzerinde doğrudan olumlu bir etkiye sahiptir (Khizindar 2012; Su vd. 2018). Turizmin olumsuz etkileri fazla ise yerel halkın algıladığı yaşam kalitesinde veya yaşam memnuniyetinde azalma meydana geldiği belirtilmektedir (Andereck ve Nyaupane 2011). Diğer yandan, yerel halkın turizme yönelik olumsuz algıları, yaşam kalitesini olumsuz olarak etkilemektedir (Su vd. 2018). Destinasyonda turizmin olumsuz ekonomik, sosyal ve çevresel etkilerinin azaltılması, yerel halkın iyi olma duygusunu geliştirecektir (Sharpley 2014). Ayrıca, yaşam kalitesinden duyulan memnuniyet, turizme desteği de beraberinde getirmektedir. Bu iki değişken arasındaki ilişkiyi doğrudan inceleyen çalışma sayısı sınırlıdır (Andereck vd. 2007; Andereck ve Nyaupane 2011; Woo vd. 2015; Eslami vd. 2019). Bu değişkenler, bahsedilen çalışmalarda gelişmiş destinasyonlarda test edilmiştir; az gelişmiş destinasyonlarda, yaşam kalitesinin turizmden nasıl etkileneceği ve yaşam kalitesi bek- lentisinin turizme desteği ne ölçüde etkilediğini inceleyen herhangi bir araştırma bu çalışma sürecinde tespit edilmemiştir. Bu kapsamda, çalışmanın $\mathrm{H} 3$, H4 ve $\mathrm{H} 5$ hipotezleri aşağıdaki gibidir:

$\mathrm{H}_{3 / \mathrm{A}}$ : Turizmin algilanan olumlu etkilerinin yerel halkın yaşam kalitesi algisı üzerinde etkisi yoktur/vardir.

$\mathrm{H}_{4 / \mathrm{A}}$ : Turizmin algilanan olumsuz etkilerinin yerel halkın yaşam kalitesi algısı üzerinde etkisi yokturl vardir.

$H_{5_{0 / A}}$ Yerel halkın yaşam kalitesi algısının turizme desteği üzerinde etkisi yoktur/vardır.

Turizm destinasyonlarında yerel halkın topluluğa bağlı olma duygusu ile turizme yönelik alg1ları arasındaki ilişki konusunda çalışmalar mevcuttur. Bu araştırmalara göre, bireylerin topluluğa bağlılığı ne kadar yüksekse turizme yönelik algiları da o oranda olumludur (Brehm vd. 2004; Eslami vd. 2019). Fakat Harrill ve Potts (2003) çalışmalarında, yerel halkın topluluğa bağlılığ ne kadar yüksekse turizme yönelik o kadar çok olumsuz alg1 geliştirdiklerinden bahsetmektedir. Bu tür bulgular ortaya koyan çalışmalara karşın, topluluğa bağlılığın turizme yönelik olumlu algiya yol açtığı belirtilmektedir (Choi ve Murray 2010). Ayrıca, bulunduğu bölgedeki topluluğa bağlı olan yerel halk, turizm gelişimini doğrudan desteklemektedir. Turizm alanyazınında, bu ilişkiyi doğrudan ve dolaylı olarak ölçen çalışmalar bulunmaktadır (Ap ve Crompton 1998; Brehm vd. 2004; Eslami vd. 2019). Bu bağlamda bu çalışmada, az gelişmiş destinasyonlarda da yerel halkın topluluğa bağlılığının turizm gelişimine olan desteğe olumlu etkide bulunacağ 1 varsayılmaktadır. Bu kapsamda çalışmanın H6 ve H7 hipotezleri aşağıdaki gibidir:

$H_{6_{0 / A}}$ Yerel halkın topluluğa bağlillğının turizmin algilanan olumlu etkileri üzerinde etkisi yoktur/vardır.

$\mathrm{H}_{7_{0 / A}}$ :Yerel halkın topluluğa olan bağhlliğının turizm gelişimine desteği üzerinde etkisi yoktur/vardır.

Açıklanan bağlamlarda belirlenen araştırma hipotezleri, Şekil 1'de gösterilmektedir. 


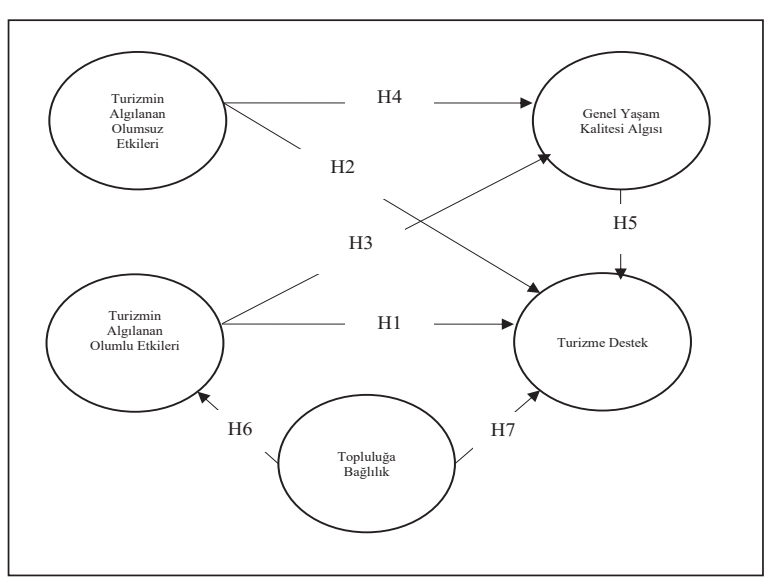

Şekil 1. Araştırma Modeli

\section{YÖNTEM}

Bu çalışmanın amacı, turizm açısından az gelişmiş bir destinasyonda yerel halkın turizme yönelik desteğini incelemektir. Oluşturulan yapısal model kapsamında, yerel halkın turizm alg1sı, topluluğa bağlılığı, genel yaşam kalitesi ve turizme desteği test edilmektedir. Araştırma kapsaminda belirlenen hipotezleri test etmek için hazırlanan anket formu ile toplanan veriler, kısmi en küçük kareler tabanlı yapısal eşitlik modellemesi ile analiz edildikten sonra elde edilen bulgular raporlanmıştır.

\section{Araştırma Alanı}

Turizmde gelişmişlik düzeyi, genellikle turizm göstergeleri (turist sayısı, turizm geliri, doğal ve kültürel çekiciliklerin turistik ürün haline gelme-

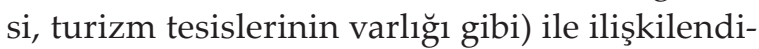
rilmektedir. Kervankiran ve Eteman (2020) bu faktörleri göz önünde tutarak Türkiye'deki illerin turizm açısından bölgesel gelişmişlik düzeylerini incelemiş ve Yozgat ilini az gelişmiş destinasyon olarak belirlemiştir. Bu doğrultuda, Yozgat ili araştırma alanı olarak seçilmiştir. Yozgat, Türkiye'nin yüzölçümü bakımından en büyük 15. şehridir ve coğrafi alanı itibariyle birbirinden farklı doğal ve kültürel çekiciliklere sahiptir. Örnek olarak, merkezde yer alan Türkiye'nin ilk milli parkı (Yozgat Çamlığı Milli Parkı), Akdağmadeni Ormanları, Kazankaya Kanyonu, Sarıkaya Hamamı, tarihi yapıları, konakları, arkeolojik sit alanları ve termal kaynakları ile önemli bir turizm potansiyeline sahiptir. Ayrıca, çevre illere ve önemli turizm destinasyonlarına (Hattuşaş ve Kapadokya) yakınlığı sebebiyle önemli geçiş alanlarından biridir. Gelecekte tamamlanacak olan hızlı tren ve havalimanı ile birlikte bölgedeki önemli turizm destinasyonlarından biri olacağ1 öngörülmektedir.

\section{Veri Toplama ve Çözümleme Süreci}

Araştırma amacı doğrultusunda az gelişmiş destinasyonda yerel halkın turizm gelişimine desteği ile çeşitli değişkenler arasındaki ilişkilerin incelenmesi için nicel teknikler tercih edilmiş ve bu değişkenlerle ilgili ifadeleri içeren anket formu ile veri toplama süreci yürütülmüştür. Anket formu üç bölümden oluşmuştur. Birinci bölümde, yerel halkın turizme yönelik olumlu (11 ifade) ve olumsuz (11 ifade) algıları ölçülmüştür (Bhat ve Mishra 2020). Bölgede turizm gelişmediği için, ifadeler katılımcılara "turizmin gelişmesi" şeklinde dönüştürülerek sorulmuştur. Örneğin, "Turizmin gelişmesi bölgede istihdam firsatlarını artırır." İkinci bölümde ise yaşam kalitesi memnuniyeti ölçeği üç ifade (Eslami vd. 2019), topluluğa bağlılık ölçeği beş ifade (Choi ve Murray 2010; Eslami vd. 2019) ve turizme destek ölçeği ise beş ifade (Çelik ve Rasoolimanesh 2021) ile ölçülmüştür. Bütün ifadeler, 5'li Likert tipi derecelendirme ile (1=Kesinlikle katılmıyorum; $5=$ Kesinlikle katılıyorum) ölçülmüştür. Son bölümde ise katılımciların demografik bilgilerine ilişkin sorulara yer verilmiştir. Kullanılan ölçeklerin kültürlerarası geçerliliği ve güvenirliği sağlanmış olup ilgili alanda sıklıkla kullanılmaktadır. Bu araştırma kapsamında ölçekler Türkçe'ye çevrilmiş ve alanında uzman üç akademisyenin görüşü alınmıştır. Ardından, 45 kişi üzerinde pilot test yapılmış ve ölçeklerin güvenirliğinin istenilen düzeyde olduğu tespit edilmiş, bu sebeple anket formundan herhangi bir ifade çıarılmadan veri toplanması uygun görülmüştür.

Araştırma evrenini, Yozgat'ta ikamet eden yerel halk oluşturmaktadır. Türkiye İstatistik Kurumu'na göre, 2020 yılında Yozgat'ta ikamet edenlerin sayısı toplamda 419.095 kişidir. Örneklem büyüklüğü bu sayı üzerinden hesaplan- 
mıştır. Kozak'a (2014) göre yüzde 95 güvenirlik düzeyinde ve evrenin heterojen dağıldı̆̆ 1 varsayıldığında 384 katılımcıdan oluşan örneklem araştırma için yeterlidir. Evrene ulaşmak güç olduğundan, kolayda örneklem ve kartopu örnekleme yöntemiyle veri toplanmıştır. Veriler, COVID-19 salgını nedeniyle 16 - 20 Şubat 2021 tarihinde çevrim içi olarak düzenlenen soru for$\mathrm{mu}$ aracılığı ile anket tekniğiyle toplanmıştır. Toplamda, 550 anket çevrimiçi olarak bölgede ikamet eden ve turizm hakkında bilgi sahibi olan katılımcılara gönderilmiştir. Katılımcıların turizm hakkında bilgi sahibi olup olmadıklarını anlamak için anketin başında turizm faaliyetine katılıp katılmadıkları veya bilgileri olup olmadıkları sorulmuştur. Fakat turizm ile bilgisi olmadığı halde anketi dolduran katılımcılar tespit edilmiş ve analizden çıkarılmıştır. Sonuç olarak, toplamda 457 anket veri analizine dahil edilmiştir.

Araştırma verilerinin analizinde, katılımcıların demografik bilgilerini sunmak ve açıklayıcı faktör analizi yapabilmek adına IBM SPSS İstatistik 24 programı kullanılırken, yapısal modeli test edebilmek için ise Smart-PLS 3 programı kullanılmıştır. Ölçüm ve yapısal model kısmi en küçük kareler tabanlı yapısal eşitlik modellemesi ile analiz edilmiştir.

\section{BULGULAR}

Öncelikle katılımcıların demografik bilgilerine yönelik bulgular ortaya koyulmuştur. Ardından ölçüm modeli incelenerek önerilen yapısal model testinden elde edilen bulgular sunulmuştur.

\section{Katılımcıların Demografik Bilgileri}

Katılımcıların demografik bilgileri incelendiğinde, çoğunluğun 26-35 yaş aralığında (yüzde 40,5), yüzde 53,2'sinin kadın ve yüzde 57,5' in evli olduğu görülmektedir. Ayrıca, katılımcıların çoğunluğunun eğitim seviyelerinin lise ve üzeri olduğu saptanmıştır. Gelir seviyelerinin genellikle $4.001-6.000$ TL (yüzde 38,5) ve 6.001 TL ve üzeri (yüzde 27,4) aralığında olduğu görülmektedir. Son olarak, katılımcıların çoğu 11 - 15 yıl (yüzde $52,5)$ boyunca Yozgat'ta ikamet etmektedir.

\section{Açıklayıcı Faktör Analizi}

Araştırmanın veri toplama aracında kullanılan ölçekler farklı çalışmalardan alındığı için, ölçeklere açılayıcı faktör analizi uygulanmıştır. Öncelikle, faktör analizine uygunluğu test edebilmek için, bütün yapıların örneklem yeterliliği Kaiser-Meyer Olkin (KMO) testi ile ölçülürken değişkenler arasındaki anlamlılığı test edebilmek için ise Bartlett Küresellik Testi kullanılmıştır. Tablo 1'de bütün yapılara ilişkin değerlere bakıldığında, KMO değerlerinin örneklem yeterliliğ i açısından uygun olduğu ve Bartlett testine göre değişkenler arasında anlamlı ve yüksek düzeyde ilişki olduğu ortaya koyulmuştur. Bu testlere göre, veri setinin açıklayıcı faktör analizine uygun olduğu belirlenmiştir.

Açılayıcı faktör analizinde, her bir ölçek faktör analizine tabi tutulmuştur. Buna göre, faktör yükleri 0,40'ın üzerinde olanlar ve öz değeri 1 'in üzerinde olanlar seçilmiştir (Alpar 2020). Bu doğrultuda, Tablo 1'de gösterildiği gibi turizmin algilanan olumsuz etkilerinden iki ifade (12. ve 17. ifadeler) faktör yükleri $0,40^{\prime} ı$ altında olduğu için faktör analizine dâhil edilmemiştir. Ayrıca, açılanan varyans oranları istenilen düzeyde olduğundan, araştırmanın bir sonraki aşaması olan ölçüm modeli test edilmiştir.

\section{Ölçüm Modeli}

Bu araştırmada, ölçeklerin ayırt edici ve yakınsak geçerliği ile ifadelerin tutarlılığını kontrol edebilmek için ölçüm modeli test edilmiştir. Tablo 1'e göre, bütün standardize edilmiş faktör yükleri, Bagozzi ve diğerlerinin (1991) önerdiği üzere 0,50'nin üzerindedir. İç tutarlılı̆̆ ölçebilmek adına, bileşik güvenirlik, Cronbach'ın Alfası ve rho_A değerlerinden faydalanılmıştır. Tablo 1'de gösterildiği üzere, bileşik güvenirlik katsayıları $0,912-0,947$ aralığında değişkenlik göstermektedir. Chin (2010) bu değerlerin 0,70'in üzerinde olduğunda ölçüm modelinin yeterli olduğuna işaret etmektedir. Ayrıca, Cronbach Alfa katsayıları da $0,85-0,94$ aralığında olup modelin yeterince güvenilir olduğunu göstermektedir (Taber 2018). Son olarak, rho_A değerlerinin 0,70'in üzerinde olması gerekmektedir. Bu doğrultuda bu çalışmada yapılara ait değerlerin bu oranın üzerinde 
Tablo 1. Açıklayıcı Faktör Analizi ve Ölçüm Modeli Sonuçları

\begin{tabular}{|c|c|c|c|c|c|c|c|c|}
\hline \multirow[b]{2}{*}{ Yapı/ifadeler } & \multicolumn{4}{|c|}{ Açıklayıcı Faktör Analizi } & \multicolumn{4}{|c|}{ Ölçüm Modeli } \\
\hline & $F Y$ & $\ddot{O}$ & $A V(\%)$ & $C A$ & $S F Y$ & rho_A & $C R$ & $A V E$ \\
\hline Turizmin Algılanan & & 6,830 & 62,09 & 0,94 & & 0,943 & 0,947 & 0,620 \\
\hline \multicolumn{9}{|l|}{ Olumlu Etkileri } \\
\hline 1 & 0,715 & & & & 0,711 & & & \\
\hline 2 & 0,733 & & & & 0,717 & & & \\
\hline 3 & 0,858 & & & & 0,849 & & & \\
\hline 4 & 0,793 & & & & 0,783 & & & \\
\hline 5 & 0,851 & & & & 0,856 & & & \\
\hline 6 & 0,839 & & & & 0,836 & & & \\
\hline 7 & 0,842 & & & & 0,840 & & & \\
\hline 8 & 0,840 & & & & 0,841 & & & \\
\hline 9 & 0,752 & & & & 0,759 & & & \\
\hline 10 & 0,692 & & & & 0,702 & & & \\
\hline 11 & 0,729 & & & & 0,746 & & & \\
\hline
\end{tabular}

Kaiser-Meyer-Olkin: 0,935

Bartlett Küresellik Testi; 3674,886

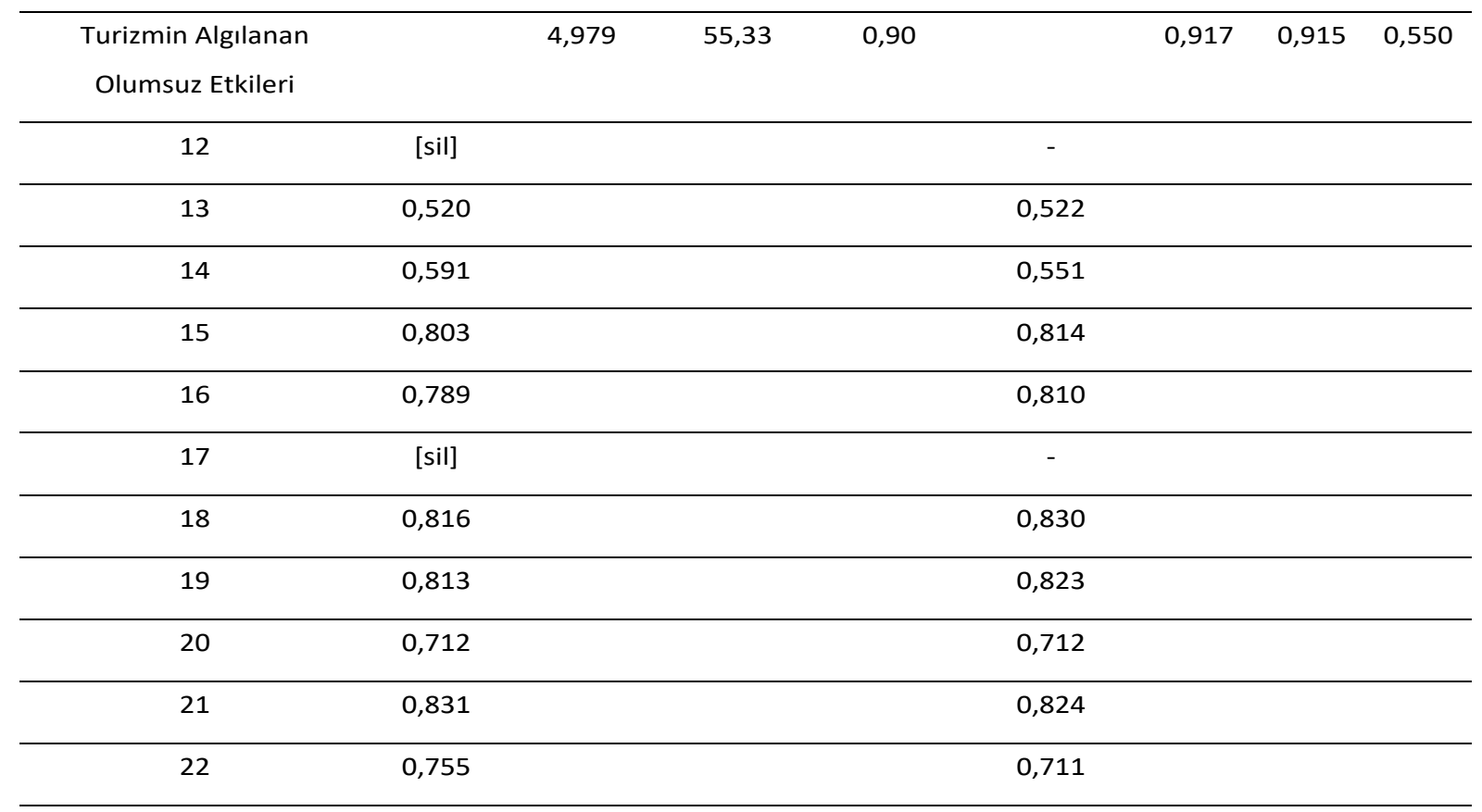

Kaiser-Meyer-Olkin: 0,894

Bartlett Küresellik Testi; 2210,199 
Tablo 1. Açıklayıcı Faktör Analizi ve Ölçüm Modeli Sonuçları (Devam)

\begin{tabular}{|c|c|c|c|c|c|c|c|c|}
\hline \multirow[b]{2}{*}{ Yapı/ifadeler } & \multicolumn{4}{|c|}{ Açıklayıcı Faktör Analizi } & \multicolumn{4}{|c|}{ Ölçüm Modeli } \\
\hline & $F Y$ & $\ddot{O}$ & $A V(\%)$ & $C A$ & $S F Y$ & rho_A & $C R$ & AVE \\
\hline Topluluğa bağlılık & & 3,671 & 73,41 & 0,91 & & 0,915 & 0,932 & 0,732 \\
\hline 23 & 0,867 & & & & 0,844 & & & \\
\hline 24 & 0,914 & & & & 0,908 & & & \\
\hline 25 & 0,761 & & & & 0,794 & & & \\
\hline 26 & 0,897 & & & & 0,882 & & & \\
\hline 27 & 0,837 & & & & 0,845 & & & \\
\hline
\end{tabular}

Kaiser-Meyer-Olkin: 0,887

Bartlett Küresellik Testi; 1526,552

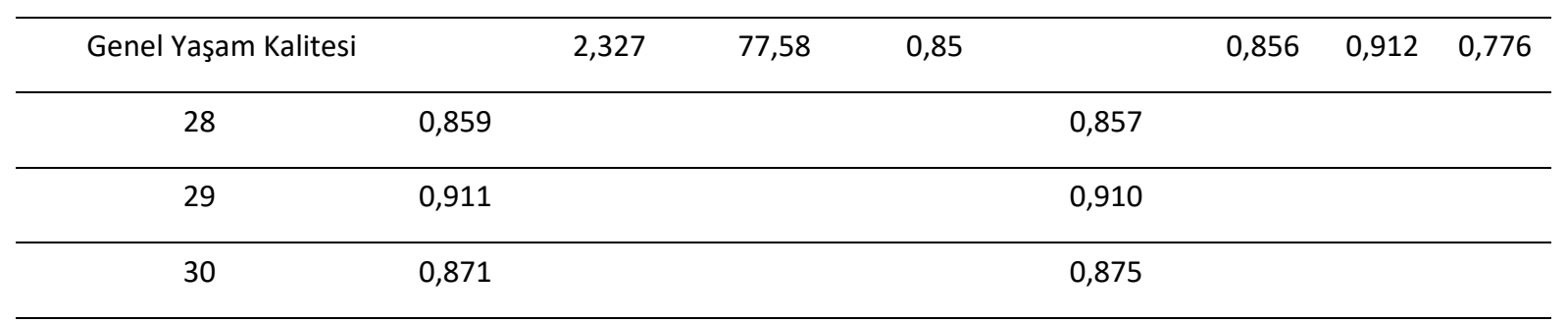

Kaiser-Meyer-Olkin: 0,714

Bartlett Küresellik Testi; 628,397

\begin{tabular}{|c|c|c|c|c|c|c|c|c|}
\hline Turizme Destek & & 3,414 & 68,27 & 0,88 & & 0,884 & 0,915 & 0,682 \\
\hline 31 & 0,779 & & & & 0,786 & & & \\
\hline 32 & 0,856 & & & & 0,861 & & & \\
\hline 33 & 0,770 & & & & 0,779 & & & \\
\hline 34 & 0,887 & & & & 0,878 & & & \\
\hline 35 & 0,834 & & & & 0,822 & & & \\
\hline
\end{tabular}

Kaiser-Meyer-Olkin: 0,791

Bartlett Küresellik Testi; 1406,996

Açıklama: FY (Faktör Yükü); Ö (Özdeğer); AV (Açıklanan Varyans); CA (Cronbach Alfa); SFY

(Standardize Edilmiş Faktör Yükleri); CR (Bileşik Güvenirlik); AVE (Ortalama Açıklanan Varyans); [sil]: Silinen ifade. 
Tablo 2. Heterotrait-Monotrait Oranı Değerleri

\begin{tabular}{ccccc}
\hline Yapılar & 1 & 2 & 3 & 4 \\
\hline Turizmin Olumlu Etkileri & & & & \\
\hline Turizmin Olumsuz Etkileri & 0,534 & & & \\
\hline Topluluğa bağlılık & 0,184 & 0,459 & 0,100 & \\
\hline Genel Yaşam Kalitesi & 0,101 & 0,139 & 0,167 \\
\hline Turizme Destek & 0,641 & 0,409 & 0,206 & \\
\hline
\end{tabular}

olduğu görülmüştür. Böylece, bu çalışmanın iç tutarlılığının sağlandığı söylenebilir.

Yakınsak geçerliği sağlayabilmek için AVE (Ortalama Açıklanan Varyans) değerinden yararlanılmıştır. Chin'e (2010) göre bu değerlerin eşik değeri 0,50 olarak belirlenmiş olup bu çalışmadaki yapılara ait AVE değerlerinin $(0,550-0,776)$ bu değerin üzerinde olduğu görülmüştür. Ayırt edici geçerlilik ise Heterotrait-Monotrait (HTMT) oranı ile sağlanmıştır. Oldukça yeni bir metot olan HTMT oranı son yıllarda sıklıkla kullanılan yöntemlerden biridir (Henseler vd. 2015). HTMT oranlarının 0,9'dan küçük olması beklenmekte- dir ve Tablo 2'ye bakıldığında bütün değerlerin 0,9'dan küçük olduğu görülmektedir. Böylelikle, veri toplama aracında kullanılan yapılar arasındaki ilişkilerin varlığı ortaya koyulmaktadır

\section{Yapısal Model}

Araştırmanın yapısal modeli, ölçüm modelinde test edilen sonuçlara göre analiz edilebilir. Buna göre, araştırmada kurulan model (Şekil 1) test edilmiştir. Elde edilen bulgular Tablo 3 ile Şekil 2'de gösterilmektedir. Yapısal modelden elde edilen bulgulara göre, topluluğa bağlılık ve genel yaşam kalitesi algısının belirleme katsayıları $\left(R^{2)}\right.$

Tablo 3. Hipotez testleri

\begin{tabular}{|c|c|c|c|c|c|}
\hline Hipotezler & $B$ & $S D$ & t-değeri & $P$ & Sonuç \\
\hline $\mathrm{TOE} \rightarrow \mathrm{TD}$ & 0,334 & 0,053 & 6,339 & 0,000 & Kabul $\left(H 1_{A}\right)$ \\
\hline $\mathrm{TOZE} \rightarrow \mathrm{TD}$ & $-0,169$ & 0,047 & 3,576 & 0,000 & Kabul $\left(\mathrm{H} 2_{\mathrm{A}}\right)$ \\
\hline $\mathrm{TOE} \rightarrow \mathrm{GYK}$ & 0,187 & 0,049 & 3,815 & 0,000 & Kabul $\left(\mathrm{H}_{3}\right)$ \\
\hline $\mathrm{TOZE} \rightarrow \mathrm{GYK}$ & 0,153 & 0,056 & 2,749 & 0,006 & Kabul $\left(\mathrm{H}_{4}\right)$ \\
\hline $\mathrm{GYK} \rightarrow \mathrm{TD}$ & 0,106 & 0,053 & 2,011 & 0,045 & Kabul $\left(H 5_{A}\right)$ \\
\hline $\mathrm{TB} \rightarrow \mathrm{TOE}$ & 0,176 & 0,056 & 3,154 & 0,002 & Kabul $\left(\mathrm{H} 6_{\mathrm{A}}\right)$ \\
\hline $\mathrm{TB} \rightarrow \mathrm{TD}$ & 0,386 & 0,053 & 7,290 & 0,000 & $\operatorname{Kabul}\left(\mathrm{H} 7_{\mathrm{A}}\right)$ \\
\hline
\end{tabular}

$R^{2}$ (Turizmin olumlu Etkisi) $=0,031 ; R^{2}$ (Turizme destek) =0,388; $R^{2}$ (Genel Yaşam Kalitesi) = 0,058

Açıklama: TOE (Turizmin Olumlu Etkileri); TOZE (Turizmin Olumsuz Etkileri); GYK (Genel Yaşam kalitesi); TB (Topluluğa Bağlılık); TD (Turizme Destek). 


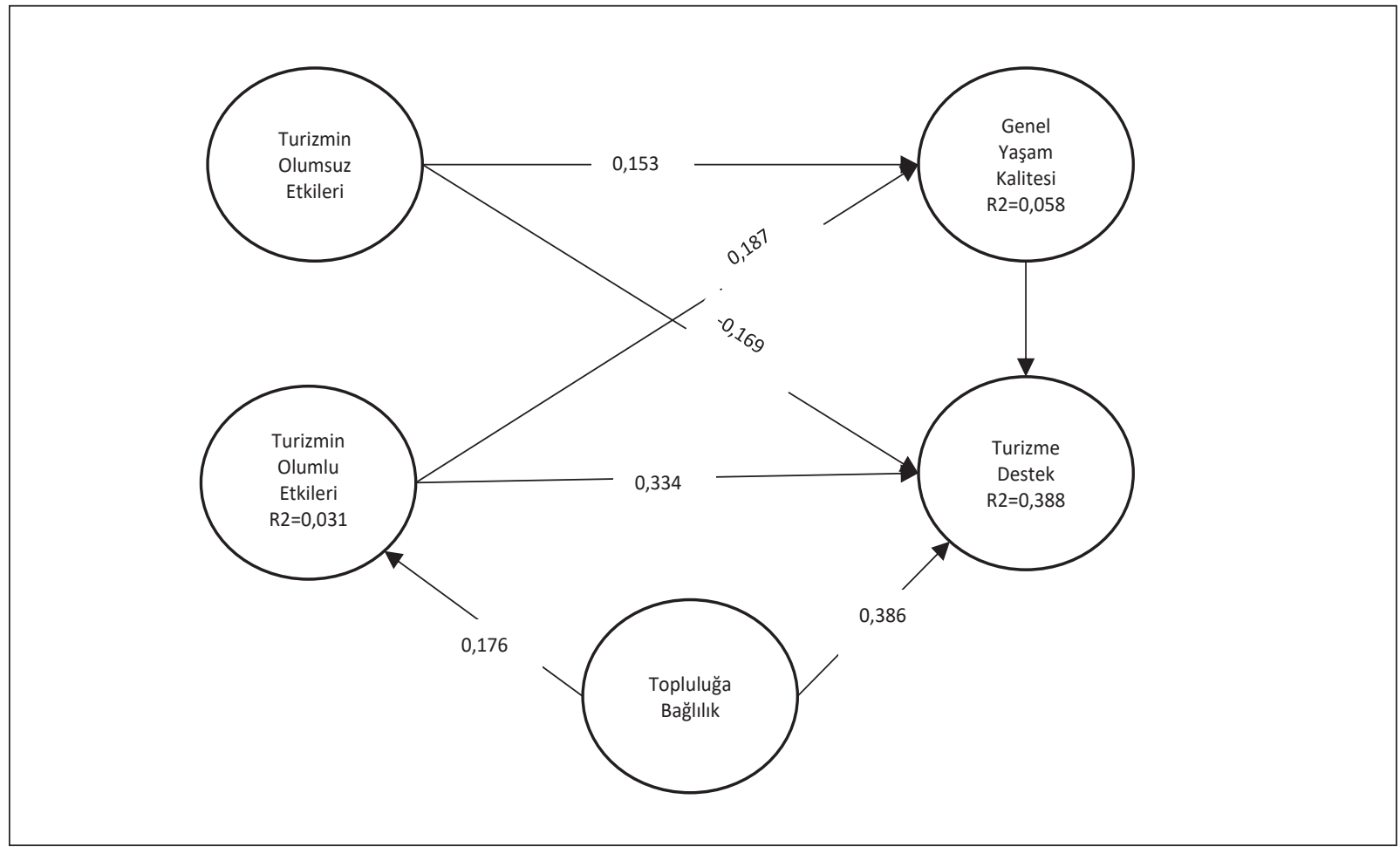

Şekil 2. Yapısal Model Sonuçları

istenilen etki düzeyine sahip değildir. Fakat turizme desteğin oranı Hair ve diğerlerinin (2016) önerdiği 0,20 eşik düzeyinin üzerindedir. Bunun dışında, araştırmada modelin uyum değerlendirmesinin sağlanabilmesi için kestirimsel uygunluk, Stone-Geisser'in Q2 değeri Tahmin Gücü Analizi (Blindfolding) ile hesaplanmıştır. Hair ve diğerleri (2016) bu değerin sıfırdan büyük olması gerektiğini belirtmiştir. Bu araştırmada, bütün değerlerin sıfırdan büyük olduğu hesaplanmıştır [Q2 (Turizmin Olumlu Etkisi) =0,018; Q2 (Turizme Destek) =0,254; Q2 (Genel Yaşam Kalitesi) = 0,040].

Araştırmada sunulan hipotezlerin anlaml1lık düzeylerini test edebilmek için mevcut veri setinin artırılmasına yardımcı olan 5.000 örnekli ön yükleme (Bootstrap) tekniği (Hair vd. 2016) uygulanmıştır. Bu sonuçlar da Tablo 3 'te ve Şekil 2'de sunulmaktadır. Buna göre, belirlenen yedi hipotezin hepsi kabul edilmiştir. Yozgat ili az gelişmiş bir destinasyon olduğundan araştırmanın bulguları da bu gelişimin olması halinde ortaya çıkacak algılar olarak yorum- lanmaktadır. Bu doğrultuda ilde turizmin gelişmesi halinde, yerel halkın algıladığ 1 olumlu $(\beta=0,334$, $t$-değeri $=6,339)$ ve olumsuz $(\beta=-0,169)$, $\mathrm{t}$-değeri $=3,576)$ turizm etkileri, turizm gelişimine yönelik desteği etkileyecektir. Ayrıca, yerel halkın algıladığı olumlu $(\beta=0,187$, t-değeri=3,815) ve olumsuz $(\beta=0,153$, $\mathrm{t}$-değeri $=2,749)$ turizm etkileri genel yaşam kaliteleriyle ilgili algılarını etkileyecektir. Araştırma bulgularına göre, genel yaşam kalitesinde yaşanan değişim, turizme desteği $(\beta=0,106$, $t$-değeri $=2,011)$ etkileyecektir. Son olarak, yerel halkın topluluğa bağlılığı ise yerel halkın algıladığı olumlu turizm etkilerini $(\beta=0,176$, $\mathrm{t}$-değeri $=3,154)$ ve turizm gelişimine desteği $(\beta=0,386, \mathrm{t}$-değeri $=7,290)$ etkileyecektir.

\section{SONUÇ}

Türkiye'de destinasyonların sahip oldukları doğal ve kültürel çekiciliklere göre turizm gelişimi ülke genelinde farklı bölgelere yayılmakta, turizm gelişim aşamaları ise her destinasyona göre farklılık göstermektedir. Her ne kadar fark$l_{1}$ aşamada olsa da yerel halkın turizme yönelik 
algıların incelenmesi turizm gelişimi açısından ve yerel halkın desteğini alabilmek için oldukça önemlidir. Araştırma bulgularına göre, yerel halkın algıladığı turizmin olumlu etkileri turizm gelişimine yönelik desteği olumlu olarak etkilerken, olumsuz etkiler ise turizm gelişimine verilen desteği olumsuz olarak etkilemektedir. Bu sonuçlar, Sosyal Değişim Teorisinin "fayda" ve "maliyet" ilkesini desteklemektedir. Buna göre, yerel halk turizmden fayda sağladığı ölçüde turizme katkı sunarken turizmin maliyetlerinin fayda ilkesinden fazla olduğunu hissettiği oranda da turizme desteğini sunmamaktadır. Bu bul$\mathrm{gu}$, hem gelişmiş destinasyonlarda yapılan çalışmalardaki (Perdue vd. 1990; Ap 1992; Gursoy vd. 2002; Nunkoo ve Ramkissoon, 2011a; Nunkoo ve Gursoy 2012; Sharpley 2014), hem de az gelişmiş destinasyonlarda yapılan çalışmalardaki (Rasoolimanesh ve Jaafar 2016; Çelik ve Rasoolimanesh 2021) bulguları desteklemektedir.

Ayrıca bu araştırmada ortaya koyulan, yerel halkın turizmin olumlu ve olumsuz etkilerine yönelik algılarının genel yaşam kalitesini alg1sı üzerindeki etkisi de, diğer çalışmaların bulgularıyla benzeşmektedir (Andereck ve Nyaupane 2011; Khizindar 2012; Moscardo 2009; Guo vd. 2014; Woo vd. 2015; Su vd. 2018). Son olarak, yerel halkın algılanan genel yaşam kalitesine ilişkin memnuniyet düzeyinin turizm gelişimine desteği etkilediği yönündeki bulgu da, önceki araştırmaları teyit etmektedir (Andereck vd. 2007; Andereck ve Nyaupane 2011; Woo vd. 2015; Eslami vd. 2019). Turizm yazınında, topluluğa bağlılık düzeyi turizme desteği ve turizmin olumlu etkilerine yönelik algıyı etkilemektedir (Brehm vd. 2004; Choi ve Murray 2010; Eslami vd. 2019). Bu araştırmanın bu bağlamdaki bulgusu da önceki çalışmaları desteklemektedir.

Araştırmadan elde edilen sonuçlar incelendiğinde, az gelişmiş destinasyonlarda yerel halkın genel olarak turizme yönelik olumlu algı içerisinde olduğu ve turizm gelişimini desteklediği anlaşılmaktadır. Bu doğrultuda, destinasyonda bulunan yerel yönetimlerin, turizm yatırımlar1na imkân tanırken, turizmin olumlu ve olumsuz etkilerini göz önünde bulundurmaları önemlidir. Çünkü en önemli paydaşlardan biri olan yerel halkın turizmin gelişimine destek vermesinin ko- şullarının, nedeninin, algılanan bu etkilere bağlı olduğu önceki çalışmalarda da görüldüğü gibi bu araştırmada da ortaya konmuştur. Bu durum, turizm gelişiminde başlangıç aşamasında olan destinasyonların sürdürülebilirliği açısından önemlidir.

$\mathrm{Bu}$ çalışmanın Yozgat ilinde yapılması, en önemli sınırlılıklardan biridir. Gelecek çalışmalarda, bu etki düzeylerinin turizmin farklı aşamalarında olan destinasyonlarda uygulanmasıyla daha kapsayıcı bir çerçeve sunulabilir ve turizmin sürdürülebilir gelişimine katkıda bulunulabilir. Ayrıca, bu çalışma nicel tekniklerle yürütülmüştür. Sonraki araştırmalarda az gelişmiş destinasyonlarda turizmin gelişmesi için yerel halkın bakış açılarını daha ayrıntılı ele alan ve turizme yönelik bilgilerinin düzey ve içeriğini irdeleyen nitel araştırma yöntemleri de verimli sonuçlar sunacaktır. Son olarak, bu çalışmanın yapısal modelinde test edilen değişkenler, çalışmaya özgü olduğundan, bu modelin farklı illerde farklı değişkenler (örnek: yer kimliği) eklenerek test edilmesi, yerel halkın turizme yönelik desteğini anlamak açısından bütüncül bir bakış açısı sağlayacaktır.

\section{KAYNAKÇA}

Alpar, R. (2020). Uygulamalı Çok Değişkenli İstatistiksel Yöntemler. Ankara: Detay Yayıncilik.

Andereck, K. L. ve Nyaupane, G. P. (2011). Exploring the Nature of Tourism and Quality of Life Perceptions among Residents, Journal of Travel Research, 50 (3): 248-260.

Andereck, K. L., Valentine, K. M., Vogt, C. A. ve Knopf, R. C. (2007). A Cross-cultural Analysis of Tourism and Quality of Life Perceptions, Journal of Sustainable Tourism, 15 (5): 483-502.

Ap, J. (1992). Residents' Perceptions on Tourism Impacts, Annals of Tourism Research, 19 (4): 665-690.

Ap, J. ve Crompton, J. L. (1998). Developing and Testing a Tourism Impact Scale, Journal of Travel Research, 37 (2): 120-130.

Bagozzi, R. P., Yi, Y. ve Phillips, L. W. (1991). Assessing Construct Validity in Organizational Research, Administrative Science Quarterly, 36 (3): 421-458.

Bhat, A. A. ve Mishra, R. K. (2020). Demographic Characteristics and Residents' Attitude Towards Tourism Development: A Case of Kashmir Region, Journal of Public Affairs, 21 (2), e2179.

Brehm, J. M., Eisenhauer, B. W. ve Krannich, R. S. (2004). Dimensions of Community Attachment and Their Relationship to Well-Being in the Amenity-Rich Rural West, Rural Sociology, 69 (3): 405-429. 
Chen, C. F. ve Chen, P. C. (2010). Resident Attitudes toward Heritage Tourism Development, Tourism Geographies, 12 (4): 525-545.

Chin, W. W. (2010). How to Write Up and Report PLS Analyses. İçinde; V. Vinzi, W. Chin, J. Henseler ve H. Wang (Editörler) Handbook of Partial Least Squares: Concepts, Methods and Application (ss. 645-689). Berlin: Springer.

Choi, H. C. ve Murray, I. (2010). Resident Attitudes Toward Sustainable Community Tourism, Journal of Sustainable Tourism, 18 (4), 575-594.

Çelik, S. ve Rasoolimanesh, S. M. (2021). Residents' Attitudes towards Tourism, Cost-Benefit Attitudes, and Support for Tourism: A Pre-development Perspective, Tourism Planning \& Development, 1-19.

Çiçek, D. ve Sarı, Y. (2018). Yerel Halkın Turizme Olan Desteği: Türkiye'deki Sakin Şehirler Üzerine Bir Araştırma, Anatolia: Turizm Araştırmaları Dergisi, 29 (2): 185-196.

Eslami, S., Khalifah, Z., Mardani, A., Streimikiene, D. ve Han, H. (2019). Community Attachment, Tourism Impacts, Quality of Life and Residents' Support for Sustainable Tourism Development, Journal of Travel and Tourism Marketing, 36 (9): 1061-1079.

Guo, Y., Kim, S. ve Chen, Y. (2014). Shanghai Residents' Perceptions of Tourism Impacts and Quality of Life, Journal of China Tourism Research, 10 (2): 142-164.

Gursoy, D., Jurowski, C. ve Uysal, M. (2002). Resident Attitudes: A Structural Modeling Approach, Annals of Tourism Research, 29 (1): 79-105.

Gursoy, D. ve Nunkoo, R. (2019). The Routledge Handbook of Tourism Impacts: Theoretical and Applied Perspectives. Londra: Routledge.

Hair, J., Hult, G., Ringle, C. ve Sarstedt, M. (2016). A Primer on Partial Least Squares Structural Equation Modeling (PLSSEM). Los Angeles: Sage.

Harrill, R. ve Potts, T. D. (2003). Tourism Planning in Historic Districts: Attitudes toward Tourism Development in Charleston, Journal of the American Planning Association, 69 (3): 233-244

Henseler, J., Ringle, C. M. ve Sarstedt, M. (2015). A New Criterion for Assessing Discriminant Validity in Variancebased Structural Equation Modeling, Journal of the Academy of Marketing Science, 43 (1): 115-135.

Kervankiran, İ. ve Eteman, F. S. (2020). Turizm ve Bölgesel Gelişme: Türkiye'de İllerin Turizm Gelişmişlik Düzeylerinin Belirlenmesi, Ege Coğrafya Dergisi, 29 (2): 125140.

Khizindar, T. M. (2012). Effects of Tourism on Residents' Quality of Life in Saudi Arabia: An Empirical Study, Journal of Hospitality Marketing \& Management, 21 (6): 617-637.

Kozak, M. (2014). Bilimsel Araştırma: Tasarım, Yazım ve Yayım Teknikleri. Ankara: Detay Yayıncilık.

Liang, Z., Luo, H. ve Bao, J. (2021). A Longitudinal Study of Residents' Attitudes toward Tourism Development, Current Issues in Tourism, 1-15.
Mccool, S. F. ve Martin, S. R. (1994). Community Attachment and Attitudes Toward Tourism Development, Journal of Travel Research, 32 (3): 29-34.

Moscardo, G. (2009). Tourism and Quality of Life: Towards a More Critical Approach, Tourism and Hospitality Research, 9 (2): 159-170.

Nunkoo, R. ve Gursoy, D. (2012). Residents' Support for Tourism. An Identity Perspective, Annals of Tourism Research, 39 (1): 243-268.

Nunkoo, R. ve Ramkissoon, H. (2011a). Developing a Community Support Model for Tourism, Annals of Tourism Research, 38 (3): 964-988.

Nunkoo, R. ve Ramkissoon, H. (2011b). Residents' Satisfaction with Community Attributes and Support for Tourism, Journal of Hospitality and Tourism Research, 35 (2): 171-190.

Nunkoo, R., Smith, S. L. J. ve Ramkissoon, H. (2013). Residents' Attitudes to Tourism: A Longitudinal Study of 140 Articles from 1984 to 2010, Journal of Sustainable Tourism, 21 (1): 5-25.

Obradović, S. ve Stojanović, V. (2021). Measuring Residents' Attitude Toward Sustainable Tourism Development: ACase Study of the Gradac River gorge, Valjevo (Serbia), Tourism Recreation Research, 1-13.

Perdue, R. R., Long, P. T. ve Allen, L. (1990). Resident Support for Tourism Development, Annals of Tourism Research, 17 (4): 586-599.

Rasoolimanesh, S. M. ve Jaafar, M. (2016). Residents' Perception Toward Tourism Development: a pre-development perspective, Journal of Place Management and Development, 9 (1): 91-104.

Sharpley, R. (2014). Host Perceptions of Tourism: A Review of the Research, Tourism Management, 42: 37-49.

Su, L., Huang, S. ve Huang, J. (2018). Effects of Destination Social Responsibility and Tourism Impacts on Residents' Support for Tourism and Perceived Quality of Life, Journal of Hospitality and Tourism Research, 42 (7): 1039-1057.

Taber, K. S. (2018). The Use of Cronbach's Alpha When Developing and Reporting Research Instruments in Science Education, Research in Science Education, 48 (6): 1273-1296.

Tosun, C. (2006). Expected Nature of Community Participation in Tourism Development, Tourism Management, 27 (3): 493-504.

Um, S. ve Crompton, J. L. (1987). Measuring Resident's Attachment Levels in A Host Community, Journal of Travel Research, 26 (1): 27-29.

Woo, E., Kim, H. ve Uysal, M. (2015). Life Satisfaction and Support for Tourism Development, Annals of Tourism Research, 50: 84-97.

Yoon, Y., Gursoy, D. ve Chen, J. S. (2001). Validating a Tourism Development Theory with Structural Equation Modelling, Tourism Management, 22 (4): 363-372. 


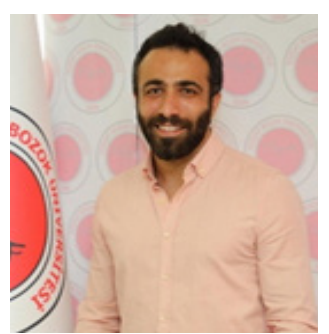

Anadolu Üniversitesi Turizm ve Otel İşletmeciliği Yüksekokulu'ndan mezun oldu (2014). Yüksek lisans derecesini İstanbul Üniversitesi'nden Turizm İşletmeciliği Anabilim Dalı'ndan (2016), doktora derecesini de İstanbul Üniversitesi'nden Turizm İşletmeciliği Anabilim Dalı'ndan aldı (2020). Yozgat Bozok Üniversitesi'nde çalışmaya başladı (2015). Ayrıca, Öğretim Elemanı Yetiştirme Kapsamında İstanbul Üniversitesi'nde Araştırma Görevlisi olarak çalıştı (2015-2017). Halen Yozgat Bozok Üniversitesi Turizm Fakültesi'nde görev yapmaktadır. Temel çalışma alanları, destinasyon pazarlaması, turist deneyimi ve turistlerin kalış süresidir. 